\title{
'Philosophy and Tradition in Africa': Critical Reflections on the Power and Vestiges of Colonial Nomenclature
}

Pascah Mungwini

Department of Philosophy and Systematic Theology

University of South Africa

mungwp@unisa.ac.za

\author{
Thought and Practice: A Journal of the Philosophical Association of Kenya (PAK) \\ New Series, Vol.3 No.1, June 2011, pp.1-19 \\ thoughtandpractice@gmail.com \\ http://ajol.info/index.php/tp/index
}

\begin{abstract}
The colonial narrative in Africa is replete with instances and processes of naming that were used not only to (re)construct social realities and (re)produce power and privilege, but also to inscribe, reify or denigrate African cultures. This work examines how the discourse of naming, specifically terms selected, stipulatively defined and applied by Western colonialists and early Western anthropologists, continue to sustain ambivalent attitudes towards the African heritage. It analyses the way in which the popular term and prefix 'traditional' is used in Africa, and argues that it can be pejorative, as it is associated with the well-established colonial custom of thinking of Africa as a continent stuck in the past. Thus the term predisposes scholars to making certain assumptions that perpetuate cultural stereotypes about African reality and experiences. The need for an analysis of the mentality that popularised its usage therefore remains pertinent. The work also attempts to address the challenge of how postcolonial Africa can engage with its past, and talk about it in terms that do not perpetuate
\end{abstract}


colonial derogation, stereotypes, assumptions, attitudes and misrepresentations of indigenous African thought and culture.

Key words. Tradition, modernity, post-colonial African philosophy, naming, colonial epithets

\section{Introduction}

In his famous article, "Pitfalls of being Different", Paulin Hountondji (1985) draws attention to a particular trajectory of thinking, set in motion by colonial anthropologists in the service of colonialism, on the supposed peculiarities of African cultures. This marked the beginning of the tragedy of (mis)representation in Africa, an issue that postcolonial African philosophy has of necessity to deal with. Everything African was construed to be 'primitive', 'savage', 'pre-logical' and 'traditional'. Postcolonial theory informs us that the colony was projected and disavowed as anachronistic. As an "Other" of the West, the African was consigned to a conceptual space defined by negation, inversion, deficiency and absence (Comaroff and Comaroff 1993; Eze 1998; Biakolo 2002; Serequeberhan 2002). The effects of this negative characterisation of the African continue to manifest themselves in diverse forms, including scepticism towards indigenous institutions and forms of knowing.

This work examines how names and terms designed and applied by colonial powers on aspects of indigenous culture and practices continue to influence the African's relationship to his/her heritage by sustaining ingrained condescension towards most things African. The work explores the historical and philosophical contexts responsible for initiating essentialised notions of culture that help to sustain cultural prejudices in Africa. Such prejudices continue to flourish masked in popular terms and names that are taken for granted in designating aspects of the African heritage. The popular term and prefix 'traditional' is one such example. This term is arguably a relic of Western ethnocentrism, and the need for an analysis of the mentality that popularised its usage remains pertinent. If applied without proper reflection the term not only predisposes scholars to making certain assumptions that encourage misrepresentation of African meanings and attitudes (Hallen and Sodipo 1997), but also perpetuates the myth of tradition versus modernity in Africa as articulating two diametrically 
opposed and distinct realities. Lauer (2006) correctly observes that when used to cut a strict cultural or metaphysical divide between evolutionary stages of social advancement, the purported distinction between 'tradition' and 'modernity' misrepresents African life and experience.

The Cartesian tendency to see things in binary opposites was instituted under the so-called civilizing mission to serve as a pretext for the colonial project. This is precisely the reason why Brodnicka (2003) argues that the tradition-modernity ideology in Africa was initiated by Europe in order to portray Africans as primitive and therefore suitable for domination. Considering the ideological prejudices of the colonial period, the term 'traditional' can be pejorative because of its association with a well-established custom of thinking of Africa as a continent stuck in the past. It harbours colonialist prejudices and racist depictions of African culture and rationality - stereotypes typical of the colonial script. For this reason, Hallen (2006) contends that 'traditional' could be one of the controversial terms still associated with indigenous cultures in postcolonial Africa. It tends to imply that Africa can be understood only in terms different from those applied to the rest of humanity today.

The term 'traditional' used as a prefix maintains what Ramose $(2006,365)$ in reference to the phrase 'African customary law versus constitutional law', describes as the 'division and hierarchisation' reflective of the fundamental historical and philosophical cleavage between the conquered and the conqueror, a division that is grounded in spurious metaphysics. To minimise the effects this cortege of stereotypes and prejudices continues to have on Africa, and to achieve parity in terms of considering African ideas, thoughts and practices as of equal value and significance to those from outside, dropping the term 'traditional' as a prefix in situations where it masks prejudices and ambiguity may be necessary. This work maintains that the prefix 'traditional' as used in colonial Africa was not innocent of politics, and today it still serves to legitimise and perpetuate Western domination over African thought. The term 'traditional this' or 'traditional that' was not just a monicker for everything African, but also a fitting epitaph of the supposedly dying African culture lying prostrate at the mercy of Western modernity and science.

The first section of this paper looks at the discourse and power of naming. This is followed by a section on the fable of tradition, which deals with the denigrated past - that which is frequently referred to as 'traditional' in the constructed and representational discourse of 
colonialism. Next, there is a brief analysis of the concept of modernity, a notion which is often (mis)construed as the converse of tradition. The last section examines the term 'traditional' as a colonial epithet, arguing for the need to rethink the use of this and other terms that continue to stoke stereotypes against African thought and culture.

\section{The Discourse and Power of Naming}

A number of scholars have contributed literature on African systems of naming, and the significance and meaning of names, from a variety of perspectives (e.g. Pongweni 1983; Kaphagawani 1991; Okere 1995; Martin 2000; Ramose 2006). In this work nomenclature is used to refer to the system of naming or simply the principles, processes and procedures of naming which involves assigning a word or phrase to a particular object or property. The purpose is to identify, to distinguish and to classify our objects of experience. This is the context within which the colonial nomenclature which constitutes the focus of this work can be understood. The practice of naming therefore is an important step in the process of distinguishing and creating an identity. Martin (2000) argues that names participate in the construction of social reality since to name is also to classify, and therefore to assign a position. The individual or object named is situated in the order of the world - in the structures of meaning invested in by a particular collectivity.

Furthermore, naming plays a significant role in the reproduction of power and privilege within the social world. With regard to geographical places, naming can be a means of claiming ownership. This is precisely the reason why Alderman (2008) argues that in themselves, names can be recognised as active and contestable processes of claiming and constructing the landscape around certain ideological visions about the past. In Africa, colonial authorities employed naming as a tool of control and a means of inscribing and reifying or denigrating certain cultural and political ideologies. In order to portray certain cultural and political ideologies as superior, inferiorisation of other cultures was an important pre-requisite. Any naming implies a relationship based on power, and to name is to confer a form of life (Martin 2000, 101).

Ramose (2008) concurs with the above position when he writes:

By giving a name to an aspect of reality those who do so arrogate unto themselves the power to define and describe that reality. Acceptance of such definition and description often entails practical consequences and these may not always be to the benefit of the named. To challenge imposed identities is in effect to question the power of the name giver and, ultimately to reverse the 
adverse negative consequences that flow from the imposed identity (Ramose 2008, 327).

The power to name, just like the power to inscribe, is in and of itself a process of creating history, hence its immense significance. It symbolizes the power to leave a mark that may continue beyond the life of the signifier. Names create symbolic and emotional attachments to places and objects, and can therefore be a form of violence against those communities excluded from the process of naming. For example, in my country, Zimbabwe, there were numerous cases of 'traditional' chiefs literally fighting and taking each other to the 'modern courts' over the naming rights of schools built by the government in contested areas of their jurisdiction.

Because names are a form of symbolic capital, tools of asserting power and a significant means of writing or rewriting history, they attract public reaction and contestation. At both the national and individual level, postcolonial Africa is replete with strong sentiments about the need to rename in order to reassert a lost identity or correct distorted history. Regarding this power and significance of naming on a people, Martin (2000) could not have put it any better when he stated:

... the power of naming perhaps does not appear anywhere more obviously than in colonial situations where it was a question of both seizing a space, and the people occupying it, and of categorising these people in such a way that the 'differences' assigned to them legitimised and perpetuated the domination resulting from this conquest (Martin 2000, 101).

Analysing the significance of naming, Okere (1995) contends that in oral societies, naming was not only a privilege but also a way of perpetuating history and hence an effective way of conferring immortality to thoughts that would otherwise not outlive the breath by which they were uttered. This possibly is the reason why the colonialists attempted to literally rename everything including both places and even people in Africa. Because names confer immortality to thought, the continued use of names coined by the coloniser, despite the changes in history, only helps to perpetuate the very objective for which they were initiated. To erase a memory, one has to do away with the name that immortalises it. This is the reason why soon after independence, many African governments embarked on a project of renaming places, particularly cities and even countries themselves. Within the context of colonialism, names served a political function: they were a means of appropriating space and history, as well as an important means of throttling competing epistemologies and denying the 
indigenous peoples the voice of expertise. Names also served as epithets to express approval or disapproval, particularly when applied in the Eurocentric and racist depiction of things African. This was a means of making the way of life of the Africans trivial, and at the same time denying them a future. This is why the term 'traditional' was not just a monicker for everything African, but a fitting epitaph of the supposedly dying African culture lying prostrate at the feet of Western modernity, religion and science.

The challenge for postcolonial philosophy today is to move away from the basic categories by which colonial culture defines other cultures and peoples (Karp and Masolo 2000). In our everyday discourse, we seem to be maintaining and valorising the categories bequeathed to us by early Western anthropologists in the service of colonialism. Analysing the process through which hegemonic social relations are achieved and maintained, Foucault introduces the idea of 'otherness'. According to Foucault, Otherness lies at the heart of the process through which the marks of difference, sexual, racial or cultural, are routinely turned into signs of inferiority and the way in which cultural hegemony is maintained by setting the valorised culture over the other. Foucault argues that Enlightenment thought itself is predicated on various strategies, expressed at both philosophical and social levels, that exclude and derogate forms of experience that cannot be readily assimilated into the notion of pure, self-sustaining rationality. The danger of 'Othering' arises when the 'Othered', whether by mistake or not, begins to celebrate the constructed identity as authentic - a problem manifested by Negritude. This is what Serequeberhan (2003) called the celebration of the inverted Eurocentric myths which Africa internalised, unwittingly, as its own self-conception which now militate against the anti-colonial postcolonial dream in Africa. Such is the story of 'tradition' in Africa.

Since naming participates in what Alderman (2008) terms the manipulation and management of public images and impressions essential for the social construction of reality and identity, the deliberate process of labelling indigenous forms of knowing and practices 'traditional' has succeeded in creating a particular image about the African heritage which needs to be contested. According to Masolo (1994), modern African intellectual history is part of a consistent escape from the harshly negated African past: "Mudimbe's invention of Africa is a brilliant general survey of how Western construction of 'primitive' and 'savage' images of Africa, particularly in historical and anthropological studies, has influenced the rise of alienated discourse and self-identity among Africans themselves" (Masolo 1994, 178). This denigrated past is what is frequently called 'traditional' in the constructed discourse. This 
work seeks to analyse this African representational discourse constructed as 'traditional', and how it impacts on the growth of African epistemologies.

\section{The Fable of Tradition}

Understanding the existential realities and social processes unfolding in postcolonial Africa requires a deliberate and thoughtful look over the shoulder to its colonial and pre-colonial cousins. It involves looking at the tragedy of the birth and tribulations of the journey of African philosophy. Tabensky $(2008,285)$ submits that "the discipline of African philosophy originates in tragedy, out of pain, confusion and rage stemming from colonial destruction; destruction that is responsible for what Fanon calls the 'negro neurosis' caused by what Biko would describe as the unbearable fusion of colonized and colonizer." Given this tragic history, the inevitable process of looking back over the shoulder in order to make sense of the present, juxtaposes in the minds of many the two contested realities in our history signified by tradition and modernity, and how the two relate.

So much has been written on the two concepts of tradition and modernity, and perspectives on what ought to be the relationship between them are numerous and varied (e.g. Hobsbawm and Ranger 1983; Masolo 1988; Gross 1992; Makang 1997; Giddens 1999; Brodnicka 2003). According to Brodnicka (2003), the installation of a tradition-modernity ideology in Africa was initiated by Europe, and the entrenching of this dualism was needed most by Europe since it served to portray Africans as primitive and therefore suitable candidates for domination. While this may account for the origin of the concept as far as Africa is concerned, it would be philosophically wrong not to acknowledge the fact that some within Africa, particularly political leaders in most former colonies, have attempted to sustain and build on this dualism through a deliberate process of the reification of 'tradition' for political expediency and as a way of achieving what Lawson (1996) calls 'marking off the West from the non-West'. By evoking the idea of a distant past, a pre-contact and non-Western past, that is, ideas of a lost paradise, politicians in postcolonial Africa have been able to use tradition instrumentally to legitimise their political aspirations and interests. Tradition has on many occasions been used as a kind of moral high ground from which to attack the West and its institutions, particularly Western democracy. As Neocosmos $(2003,17)$ has noted, "different aspects of an idealised tradition were drawn upon by different postcolonial leaders at different ends of the political spectrum in their attempts at nation-building and in order to 
legitimise different forms of authoritarian developmentalism, (eg. Nyerere's Ujamaa and Mobutu's Authenticite)." Consequently, it can be argued that although the idea of tradition versus modernity steps onto the scene and assumes its ideological significance as a result of the colonial master's desire to name, to distinguish and dominate, it has since been adopted and applied in the service of, and by, Africa's own postcolonial leaders.

That the dualism between tradition and modernity is in and of itself an invention of colonialism cannot be strongly contested. What is termed 'traditional African culture' is nothing else other than a body of reified 'tradition' invented by colonial administrators, missionaries, elders and anthropologists (Ranger 1983, 262). Unlike living traditions which are dynamic, invented traditions are characteristically invariant, employing fixed ritual routines and stereotypical symbols. The installation of the duality of tradition versus modernity in Africa was itself an inevitable outcome of the European 'civilising' mission in Africa. Lawson (1996, 2) acknowledges that "the language and forms of colonial administration, combined with the influence of earlier modes of political sociology and anthropology and then with schools of thought associated with modernisation and development, have combined to produce an image of tradition that is construed conceptually in direct opposition to what is thought to be modern or Western or both". The colonial state as a regime of modern power became identified and identifiable with universally valid forms of reason and knowledge which rejected others as inferior and outdated. This ethnocentrism and elitist posture of epistemic superiority by the West expressed in the uncompromising nature of Western science and its active negation of anything not itself, has affected the African in many respects. In order to properly understand the African mind and existence today, Osha $(1999,163)$ argues that we have to "estimate the distance between a past disfigured by the decisive onslaughts of a colonial encounter and the exigencies of the perplexing machinations of modernity."

Tracing the historical usage of the term tradition, Giddens (1999) makes an interesting observation, though by no means uncontested, that in medieval times the generic notion of tradition as it is understood today did not exist. Instead, it is a product of the last two hundred years in Europe, and hence a creation of modernity. Etymologically the word tradition comes from the Latin word tradere, which means to transmit, or give something to another for safekeeping. As noted by Giddens, "tradere was originally used in the context of Roman Law, where it referred to the laws of inheritance. Property that passed from one generation to another was supposed to be given in trust-the inheritor had obligations to protect and nurture 
it." Giddens (1999) goes on to assert that it is the $18^{\text {th }}$ century Enlightenment that can be blamed for giving tradition a bad name by reducing it to the shadow side of modernity and conflating it with dogma and ignorance, prompting society to want to disentangle itself from it. It is probably true that since its inception, science, as a canon, has been proud of its own self-image and defied integration with other forms of knowledge. This self-aggrandising attitude of science was aptly captured by Lauer in the following passage:

Due to the historical circumstances in Europe that gave rise to the "New Science" of the early 1600 s, ...the intellectual establishment of Europe adopted a posture of disdainful mistrust and extreme skepticism toward any new system of justifying and authorizing knowledge about nature. The first modern scientists needed to adopt an exclusionary posture of self-validation in order to build confidence in their innovative methods and results. In the effort to establish their legitimacy, they rejected all competing techniques of knowledge-gathering as wholesale quackery and nonsense. This was a reaction to the traumatic effects of the Reformation in the 1500s (Lauer 2006, 3).

To understand tradition in its proper context would therefore require processes of getting to grips with the cultural context that characterised the Age of Reason, and disentangling ourselves from the prejudices of the Enlightenment, a feat that may prove difficult if not impossible. The effect the Enlightenment had on tradition in Europe was transferred with added ferocity to other cultures outside Europe such as Africa. Given the conventional European conception of Africa as a "dark continent", it was inevitable that the term 'traditional' became the 'appropriate' description of everything African from culture, customs, religious beliefs, ceremonies, institutions, values, practices to political systems. Not only did 'traditional' become a new identity tag and universal prefix for Africanness, but it also became an umbrella nomenclature in place of the so-called magical, primitive and illogical African epistemologies consistent and definitive of Hegel's 'Africa Proper'.

Whereas the Enlightenment was experienced as emancipatory within the context of the West, the same cannot be said about Africa. The Enlightenment was characterised by its own duplicity, where on one hand it subscribed to the ideals of universal humanity and democracy, but on the other, it engaged in the imperial and colonial subjugation of other

\footnotetext{
1 This is an electronic version of A. Giddens, (1999) Reith Lecture 3: "Tradition" http://news.bbcco.uk/hi/english/static/events/reith_99 for which there is no pagination.
} 
races. Critics such as Eze could not help it but raise this crucial question: "could the same European modernity and Enlightenment that promoted 'precious ideals like dignity of persons' and 'democracy' also be so intimately and inextricably implicated in slavery and colonial projects?” (Eze 1998, 217).

Through colonialism, Africa was invented as 'traditional', and the name 'traditional' became synonymous with African culture and all its paraphernalia. In their bid to reassert African humanity and celebrate the African personality, philosophies such as Negritude paradoxically colluded with the ethnocentrism of Europe by agreeing to the equation 'reason is white and emotion is black'. Through such complicity, 'tradition' became politically and emotionally charged and something to celebrate as an identity, further entrenching the invented dichotomy between tradition and modernity within the African context. Celebrating African tradition was of necessity the premise and goal of Negritude, which was in and of itself a journey by Africans to rediscover their past, their roots and heritage (Ahluwalia 2001). The irony, however, is that this important attempt to rediscover the African past has also strengthened the use of the term 'traditional' as uniquely African and the opposite other of modernity. As is the case, concepts developed and applied to capture specific aspects of a people's attributes almost always carry an ideological baggage, particularly if they are developed and applied by somebody from outside that culture. Ter Haar and Ellis (2009) lamented one such development within the field of religion, and particularly took exception to the continued (mis)use of such concepts as occult, magic, and witchcraft even in contemporary scholarship, despite the fact that such concepts carry serious ideological baggage traceable to their application by colonialists and colonial scholars:

Continued use of these terms (magic, occult, witchcraft) is flawed by their association with a long tradition of thinking of Africa as a continent stuck in a traditional past, to be understood only in terms different from those applied to the rest of humanity today. The choice of language by academics is a matter of great importance. As Harold Turner long ago noted in regard to Africaninitiated churches, 'our approach to any range of phenomena is both revealed and influenced by the names we bestow upon it' .... Our point is not to argue that 'magic', 'witchcraft' or 'the occult' do not deserve to be debated, but that they cannot be understood in their proper historical and moral context as long as the debate is couched in a language that is so heavily loaded (ter Haar and Ellis 2009, 399, 400).

Given the ideological weight that a term such as 'traditional' carries and the misconceptions that it has caused and continues to fuel about Africans, one cannot help but wonder why it should not be possible to discard this relic of colonial nomenclature altogether. This is 
probably the reason why conceptual decolonisation is necessary in Africa. Wiredu (1996) identifies conceptual decolonisation as a process of avoiding or reversing through a critical conceptual self-awareness the unexamined assimilation in our thought of the conceptual frameworks embedded in the foreign philosophical traditions that have had an impact on African life and thought. Several decades after independence we still find ourselves mired in reified and hegemonic categories of thinking that were put in place in the service of colonialism, terms that characterise Africans as primitive and therefore appropriate candidates for domination.

Over the years the use and meaning of the term 'traditional', as one of those essential attributes used to characterise sub-Saharan cultures, has come under increasing scrutiny. Debate has been split over, firstly, those who would want to hold fast to the concept and continue to insist that the term does refer to something about the mentality and/or social practices of these societies that is unique; secondly, there are those who view the term as a relic of Western ethnocentrism that should be eliminated from the technical vocabulary of African studies, as its continued use predisposes scholars to make certain assumptions that encourage misrepresentations of African meanings and attitudes; and, finally, there are those who think it can still be of value if its terms of reference are clarified and stripped of pejorative elements (Hallen 2006, 275-6). Hallen and Sodipo (1997) regard the term 'traditional' within the context of modern Africa as a relic of Western ethnocentrism that should be eliminated from the vocabulary of African studies: "We think it best to discontinue use of the word 'traditional' with reference to African systems of thought. Its use predisposes scholars to make certain assumptions that encourage misrepresentations of African meanings and attitudes" (Hallen and Sodipo 1997, 125). While not everybody may agree with the position they have taken regarding the continued use of the concept to designate African thought systems in general, the point they make is crucial.

Part of the reason why African cultural ideas remain marginalised today is that they are considered to be an unnecessary dead weight from the past that stubbornly hangs on to the present; and like the biblical legendary story of shaking off the dust from one's feet, 'tradition' literally induces society to shake it off on the pilgrimage to Enlightenment or modernity. A cue can be taken from what Eze proposes regarding the equally controversial and potentially misleading concept 'postcolonial', that "in light of many other factors not 
unconnected with the colonial and neo-colonial nature of Africa's relationship with the West, the 'post' of the 'postcolonial' African philosophy has to be written under erasure, or more conveniently, in brackets....erasure or brackets serves as signal and pointer to the unfulfilled dreams of independence achievements..." (Eze 1998, 219). The same logic can be extended to the term 'traditional' each time it is used as a prefix to qualify most things African in contemporary times.

\section{Modernity}

So much has been written about modernity from socio-historical and philosophical perspectives, that there is no need to embark on a similar exercise in this work. I acknowledge the historical effects of modernity in the socio-cultural sphere of African lives, and the various processes of cultural metamorphosis it has triggered and continues to catalyse in Africa. Modernity is a complex phenomenon, and the experiences of modernisation across the world have been varied and multifarious, yielding a host of modernities such as first world modernities, third world modernities, Indian modernities and African modernities, among others. As Chatterjee observes, "there cannot be just one modernity irrespective of geography, time, environment or social conditions. The forms of modernity will have to vary between different countries depending upon specific circumstances and social practices" (Chatterjee 1997, 8). The African experiences of modernity and the concomitant creation of African modernities is a highly complex phenomenon, that is at the same time continuously unfolding. Far from being a single universal and uniform process with a predetermined end, modernity has taken innumerable and often unanticipated directions: it has become more of a multivalent phenomenon. The interface of Western modernity and African indigenous cultures has produced varied outcomes that manifest in multifarious forms constituting African modernities.

When Immanuel Kant and other Western philosophers of the Enlightenment proclaimed their views about modernity as an Age of universal exercise of reason, the implication was that 'becoming modern' is measurable and measured by the extent to which societies move away from tutelage of, and dependence on, the authority of tradition. European colonisers forced this position on Africans as a self-evident truth which they of necessity had to put into practice if at all they wanted to be accommodated in the privileged bracket of homo rationalis. This became the source of the appeal of the modern as the up-to-date and rational compared to the static, archaic and oppressive past. In spite of the problems relating to the 
African past, there is growing consensus that the past can be used to provide a foundation for African development. However, the major challenge that remains for contemporary African scholars is how to engage with this past, how to talk about it in language that does not perpetuate colonial derogation, stereotypes, assumptions and misrepresentations of African culture. Language is crucial in the construction of subjectivities and in shaping attitudes. We must therefore refrain from playing the game according to the rules set by the coloniser, hence the need for conceptual decolonisation.

\section{The Epithet 'Traditional'}

Categories of cross-cultural cognition did not lose their substance with the end of classical colonialism; instead, they have continued, and are expressed in several instances of seemingly neutral nomenclature inherited from colonialism to describe African reality. Among the host of terms that continue to denigrate Africa are 'traditional African healer', 'traditional African law/African customary law', 'traditional African morality/ethics', 'traditional African epistemology', 'traditional African medicine', 'traditional African religion', 'traditional African chiefs', to cite a few examples relevant to the present discussion. The thread that runs through all these terms is the colonial and old philosophy of signification, identification and differentiation in the same mould as that of primitive/civilised, traditional/modern, illogical/logical, irrational/rational, white/black, in short, them/us, that typified the so-called conventional Western conception of the African mentality. The danger with the terms prefixed 'traditional' is that they pretend to present an authentic position on things African, when in reality they continue to mask the privileged position accorded to the so-called modern.

By persistently referring to African thought and practice as 'traditional' postcolonial discourse, without knowing it, African scholars continue to subordinate and marginalise the African heritage and its possibilities to contribute to the present. The name 'traditional this' or 'traditional that' denies contemporaneity to African ideas, beliefs and practices. In fact, the reason why it has been called an epithet here is that the term can be disparaging, and in some cases, outrightly abusive in so far as its representation of African thought is concerned. Besides, this is what the coloniser has always sought to achieve. This nomenclature maintains what Ramose $(2006,365)$, in reference to the phrase 'African customary law versus 
Constitutional law', describes as the 'division and hierarchisation' reflective of the fundamental historical and philosophical cleavage between the conquered and the conqueror. Whereas Ramose (2006) argues against the injustice entailed in the continued use of the term 'African customary law' within the South African postcolonial context, this work sees injustice in the celebration of the very concept 'traditional' as a common prefix to describe African practices, ideas and institutions. Arguing a case for African customary law, Ramose declares:

Hierocratic reasoning (where African customary law is subordinated to the foreign law which is now ironically the Constitutional law and law of land in postcolonial Africa) must not be permitted to prevail.....Customary law is living testimony to the prevailing conflict of values between the successors in title to the unjust wars of colonisation and the indigenous peoples conquered in those wars. The resolution of this clash of values and cultures lies ultimately in conceding parity to legal paradigms existing in South Africa; in that way, it allows for genuine and practicable legal pluralism. In this the later context, (and for me this is the most important) 'African customary law' shall assume the name 'African law' to demonstrate that it is law equal to any other law anywhere on our planet Earth" (Ramose 2007, 327) ${ }^{2}$.

Two ideas that Ramose identifies, and that are of fundamental significance to the argument proffered in the present paper, are: the need for parity and the rationale of 'renaming' and in this case renaming 'African customary law' as 'African law'. The use of the term 'traditional' to prefix most African practices, beliefs and ideas denies them parity with those inherited from outside. Indeed, it helps to maintain and entrench not only the difference, but superiority of Western institutions and values by denying African ideas and practices the right to belong to the present age. In fact, one may not be far off the mark if one inferred that one of the reasons why African epistemologies are failing to impose themselves unequivocally on contemporary society may have something to do with the nomenclature we have maintained since colonialism. The paradox is that in an attempt to carve and assert an identity through the prefix 'traditional', we have also rendered most things African anachronistic. To bring an end to the long list of stereotypes and misrepresentations, and achieve parity in terms of considering African thought and practice as of equal value to those from outside, dropping the term 'traditional' as a prefix in situations where it masks prejudices or ambiguity may be necessary. Discarding this relic of colonial nomenclature can allow us to write, present or talk

\footnotetext{
${ }^{2}$ What appears in italics is my own addition.
} 
about African values, African kings, and African chiefs (although the term chief itself is also a colonial coinage to distinguish and downgrade African kings from the monarchy or kings in Europe), African healers, African law, African epistemologies, African religions, etc. These are crucial and significant aspects of culture that constitute who we are as a people that need to be protected against continued derogation, for which renaming and rebranding are necessary.

Language is a very important tool for constructing social images and identity. As such, the terminology we use to talk about specific practices can influence attitudes in a significant way. It is reasonable to assume that before the arrival of outsiders, Africans took most of their realities for granted, including their color, identity, and even their epistemologies. The 'traditional' healer, like his/her compatriot the 'traditional chief' existed only as 'doctor' and 'king' respectively. Their new identity tag is a product of the European gaze - a creation of European ethnocentrism - hence the names resonate with the conceptual tyranny of Europe. The perception persists that the 'traditional' healer remains locked in the practice of primitive magic, despite the reality of change due to processes of adoption and adaptation to their practice through the influence of modernity. Some of them are even urbanized, globalised and highly educated. Africans need to try and think in their own African languages to uncover the intelligibility that underpins most concepts and names inherited from the colonialists' terminology: this is the prerequisite to conceptual decolonization. In my Shona language, the name for what is today referred to as a 'traditional' healer is n'anga, which literally means an expert in medicine - a medical doctor. In order to deny the African doctor his/her voice of expertise, his/her identity and knowledge had to be prefixed as such to carry the tag of being pre-scientific, mythical and rudimentary. While the 'traditional' chief was constructed as the opposite of the European king, the 'traditional' healer, and the witchdoctor were recreated as the converse other of the Western trained doctor and scientist. With the complicity of Christianity, the African healer became not only a quack, but the devil's incarnate. The infamous Western sponsored African movies are testimony to this. To this day, consulting a traditional healer is stigmatized in many circles as unChristian and a sign of being uneducated, and for that reason many prefer to visit these healers under the cover of darkness. 
As Hountondji (2002) puts it, the problem today is that, in the context of colonial domination, we have to a large extent internalised the discourse of our former masters on our cultures, their denigrating views on African thought and life. A good understanding of the mentality that originally assigned the term 'traditional' to African ideas, practices and institutions justifies the need to treat the term 'traditional' with some amount of suspicion. Wiredu (1998) warned us on how not to compare African traditional thought with Western science. Using the same logic, this paper proposes a caveat on how not to perpetuate the Western ethnocentric and ideological prejudices against postcolonial Africa through certain forms of terminology. Africans' epistemic and cultural advantages remain suppressed under the influence of received colonial stereotypes that promote false notions of cultural essentialism, and I see no reason why it should not be possible to discard this relic of colonial nomenclature altogether.

\section{Conclusion}

The gospel of spiritual and cultural metamorphosis and the injustices of nomenclature propounded by European colonialists still continue in many guises in postcolonial Africa, and therefore require constant vigil. The prefix 'traditional' in Africa is often guilty of the politics of rationality, and remains one of the controversial terms still associated with African cultures. This work has contended that the term is an ideological construct located within the colonial script and pregnant with stereotypes about African culture and mentality. Besides being pejorative, its continued use predisposes scholars to making certain assumptions that encourage misrepresentations of African culture. The worry is that to continue to take for granted the use of this term as a prefix to African thought and practice ascribes a negative connotation of backwardness and unthinking conservatism to the whole system. Consequently, as African philosophers struggle to reassert the African identity, it may now be time for them to dispense with inappropriate nomenclature from the colonial dictionary.

\section{References}

Ahluwalia, P. 2001. Politics and Postcolonial Theory: African Inflections. London: Routledge.

Alderman, D.H. 2008. "Place Naming and Interpretation of Cultural Landscapes". Graham, B. and P. Howard eds. The Ashgate Research Companion to Heritage and Identity. Hampshire: Ashgate Publishing Ltd, pp.195-214. 
Biakolo, E. 2002. "Categories of Cross-cultural Cognition and the African Condition". Coetzee, P.H. and A.P.J. Roux eds. Philosophy from Africa: A Text with Readings. Oxford: Oxford University Press, pp.9-19.

Brodnicka, M. 2003. "When Theory Meets Practice: Undermining the Principles of Tradition and Modernity in Africa". Journal on African Philosophy, Vol.2, http://www.africaknowledgeproject.org/index.php/jap/article/view/12

Chatterjee, P. 1997. Our Modernity. Dakar: CODESRIA.

Comaroff, J. and J. Comaroff eds. 1993. Modernity and its Malcontents: Ritual and Power in Postcolonial Africa. Chicago: University of Chicago Press.

Eze, E.C. ed. 1997. Postcolonial African Philosophy: A Critical Reader. London: Blackwell Publishers.

Eze, C. E. 1998. "Modern Western Philosophy and African Colonialism". Eze, E.C. ed. African Philosophy: An Anthology. Oxford: Blackwell Publishers, pp.213-221.

Giddens, $\quad$ A. $1999 . \quad$ "Tradition". Reith 3. http://news.bbc.co.uk/hi/english/static/events/reith-99

Gross, D. 1992. The Past in Ruins: Tradition and the Critique of Modernity. Massachusetts: University of Massachusetts Press.

Hallen, B. and J.O. Sodipo. 1997. Knowledge, Belief and Witchcraft: Analytic Experiments in African Philosophy. Stanford: Stanford University Press.

Hallen, B. 2006. African Philosophy: The Analytic Approach. Asmara: Africa World Press.

Hobsbawm, E. and T. Ranger eds. 1983. The Invention of Tradition. Cambridge: Cambridge University Press.

Hountondji, P. 1985. "Pitfalls of Being Different". Diogenes, Vol.33 No.46, pp.46-56.

--. 2002. "Knowledge Appropriation in a Postcolonial Context". Hoppers, C.O. ed. Indigenous Knowledge and the Integration of Knowledge Systems: Towards a Philosophy of Articulation. Claremont: New Africa Books, pp.23-38.

Kaphagawani, D.N. 1991. "Bantu Nomenclature and African Philosophy". Oruka, H.O. ed. Sage Philosophy: Indigenous Thinkers and Modern Debate on African Philosophy. Nairobi: ACTS Press, pp.179-196.

Karp, I. and D. Masolo eds. 2000. African Philosophy as Cultural Inquiry. Bloomington: Indiana University Press.

Kuper, A. 1988. The Invention of Primitive Society. London: Routledge.

Lauer, H. 2006. "Rethinking 'Tradition vs Modernity': the Social Construction of the HIV/AIDS Crisis in Africa". www.aciafrica.org/journal/jasv7nly06.pdf

Lawson, S. 1996. Tradition Versus Democracy in the South Pacific. Cambridge: Cambridge University Press. 
Makang, J.M. 1997. "Of the Good Use of Tradition: Keeping the Critical Perspective in African Philosophy". Eze, E.C. ed. Postcolonial African Philosophy: A Critical Reader. London: Blackwell Publishers, pp.324-338.

Martin, D.S. 2000. "The Burden of the Name: Classifications and Constructions of Identity: The Case of the 'Coloureds' in Cape Town (South Africa)". African Philosophy, Vol.13 No.2, pp.99-124.

Masolo, D.A. 1988. African Philosophy in Search of Identity. Indianapolis: Indiana University Press.

Mudimbe, V.Y. 1988. The Invention of Africa. London: James Carrey.

Neocosmos, M. 2003. "The Contradictory Position of 'Tradition' in African Nationalistic Discourse: Some Analytical and Political Reflections”. Africa Development, Vol.28 No.1\&2, pp.17-52.

Osha, S. 1999. "Kwasi Wiredu and the Problems of Conceptual Decolonisation". Quest: An African journal of philosophy, Vol.13 No.1\&2, pp.157-163.

Okere, T. 1995. "Names as Building Blocks of an African Philosophy". http://www.crvp.org/book/Series02/II-3/CH8.htm

Pongweni, A.J. 1983. What's in a Name: A Case Study of Shona Nomenclature. Gweru: Mambo Press.

Rabinow, P. ed. 1984. The Foucault Reader. New York: Penguin Books.

Ramose, M.B. 2006. "The King as Memory and Symbol of African Customary Law". Hinz, M.O. and H.K. Patermann eds. The Shade of New Leaves: Governance in Traditional Authority: A Southern African Perspective. Berlin: Lit Verlag Munster, pp.351-374.

--. 2007. "In Memoriam: Sovereignty and the 'New' South Africa". Griffith Law Review, Vol.6 No.2, pp.310-329.

--. 2008. "Birth, Death and Truth: An Essay in Memory of Emmanuel Chukwudi Eze". South African Journal of Philosophy, Vol.27 No.4, pp.325-331.

Ranger, T. 1983. "The Invention of Tradition in Colonial Africa". Hobsbawm, E. and T. Ranger eds. The Invention of Tradition. Cambridge: Cambridge University Press, pp.211-262.

Serequeberhan, T. 2003. "The African Anti-colonial Struggle: An Effort at Reclaiming History". Philosophia Africana, Vol.6 No.1, pp.47-58.

Tabensky, A.P. 2008. "The Postcolonial Heart of African Philosophy”. South African Journal of Philosophy, Vol.27 No.4, pp.285-295.

Ter Haar, G. and S. Ellis. 2009. "The Occult Does not Exist: A Response to Terence Ranger". Africa: The Journal of the International African Institute, Vol.79 No.3, pp.399-412.

Wiredu, K. 1996. Cultural Universals and Particulars. Bloomington: Indiana University Press. 
'Philosophy and Tradition in Africa': Critical Reflections on the Power and Vestiges of Colonial Nomenclature 19

--. 1998. "How not to Compare African Thought with Western Thought". Eze, C.E. ed. African Philosophy: An Anthology. Oxford: Blackwell Publishers, pp.193-199. 